\title{
Comparison of anti-inflammatory and clinical effects of beclomethasone dipropionate and salmeterol in moderate asthma
}

\author{
E. Bacci*, A. Di Franco*, M.L. Bartoli*, S. Carnevali*, S. Cianchetti*, F.L. Dente*, \\ D. Giannini*, B. Vagaggini*, L. Ruocco\#, P.L. Paggiaro*
}

Comparison of anti-inflammatory and clinical effects of beclomethasone dipropionate and salmeterol in moderate asthma. E. Bacci, A. Di Franco, M.L. Bartoli, S. Carnevali, S. Cianchetti, F.L. Dente, D. Giannini, B. Vagaggini, L. Ruocco, P.L. Paggiaro. (C) ERS Journals Ltd 2002.

ABSTRACT: Inhaled corticosteroids and long-acting $\boldsymbol{\beta}_{\mathbf{2}}$-agonists effectively control asthma symptoms and improve airway function. The effects of beclomethasone were compared with those of salmeterol on markers of eosinophilic inflammation in induced sputum in steroid-naïve asthmatic subjects with moderate asthma.

Fifteen moderate asthmatics were treated with either beclomethasone dipropionate $(500 \mu \mathrm{g}$ b.i.d) or salmeterol $(50 \mu \mathrm{g}$ b.i.d) for 4 weeks, according to a randomised, double-blind, parallel-group study design. All patients underwent spirometry, methacholine test, sputum induction, and blood sampling before and after 2 and 4 weeks of treatment. They also recorded daily symptoms and peak expiratory flow (PEF).

Sputum eosinophils, eosinophil cationic protein (ECP) and eosinophil protein X (EPX), and blood eosinophils, as well as the forced expiratory volume in one second (FEV1) and morning PEF, significantly improved after beclomethasone but not after salmeterol. PEF variability, the symptom score and rescue $\beta_{2}$-agonist use significantly improved after both treatments, although the improvement in the symptom score tended to be greater after beclomethasone. After 2 and 4 weeks of beclomethasone treatment, both serum ECP and EPX decreased. With salmeterol, only serum EPX decreased, after 4 weeks. Bronchial hyperresponsiveness to methacholine did not change after either treatment.

The authors conclude that beclomethasone, but not salmeterol, substantially improves airway inflammation in asthma. Beclomethasone also had an overall greater clinical effect, although the improvement in symptoms and peak expiratory flow variability was similar after both treatments.

Eur Respir J 2002; 20: 66-72.

\author{
*Cardiothoracic Dept, Respiratory \\ Unit, University of Pisa, and ${ }^{\#}$ Labora- \\ tory Unit, Cisanello Hospital, Pisa, \\ Italy. \\ Correspondence: P.L. Paggiaro \\ Dipartimento Cardiotoracico \\ UO Fisiopatologia Respiratoria \\ Ospedale Cisanello \\ via Paradisa 2 \\ 56124 Pisa \\ Italy \\ Fax: 39050580124 \\ E-mail: ppaggiaro@qubisoft.it
}

Keywords: Airway inflammation asthma

induced sputum

Received: November 62000

Accepted after revision: January 23 2002
It is now well established that asthma is associated with airway inflammation [1]. Inhaled corticosteroids are the drug of choice in the treatment of asthma because they provide the best anti-inflammatory treatment available [2]. Inhaled corticosteroids improve asthma symptoms and pulmonary function [3, 4], and have been shown to decrease airway inflammation $[5,6]$. Several noninvasive markers of airway inflammation have been used in past years in order to evaluate the efficacy of anti-asthma drugs [7, 8], and eosinophilia in induced sputum has been shown to be a sensitive marker of spontaneous or drug-induced changes in airway inflammation $[9,10]$.

Oral corticosteroids significantly reduce eosinophils in induced sputum [10]. The efficacy of inhaled corticosteroids on sputum eosinophils in asthmatic subjects has been studied by several authors, showing conflicting results. While low-dose inhaled beclomethasone dipropionate or budesonide only marginally reduced sputum eosinophilia in subjects with mild-tomoderate asthma [11, 12], high-dose $(1,600-2,000 \mu \mathrm{g}$ daily) inhaled budesonide or fluticasone significantly reduced sputum eosinophilia in mild asthmatics $[13,14]$.

Long-acting $\beta_{2}$-agonists, such as salmeterol, are recommended in the treatment of moderate-to-severe asthma in addition to inhaled corticosteroids [2], because they control asthma symptoms and improve lung function in asthmatic patients [15]. However, they have also been shown to have some antiinflammatory properties in vitro [16], but whether they have the same effects in vivo is still a controversial area [17-19].

In the present study, the effects of beclomethasone were compared to those of salmeterol on markers of eosinophilic inflammation in induced sputum, in a group of steroid-naïve asthmatic subjects with symptoms of moderate asthma. The dose of inhaled steroid was as recommended by the international guidelines for asthma of moderate severity. In addition, the effects on sputum markers were compared with the effects on the same markers in blood. 


\section{Material and methods}

\section{Subjects}

A total 33 patients with symptomatic, moderate asthma, recruited from the clinics of the Cardiothoracic Dept Respiratory Unit (University of Pisa, Pisa, Italy) were screened. The diagnosis of asthma was made according to internationally accepted criteria [2], after assessing reversible airway obstruction and/or nonspecific bronchial hyperresponsiveness to methacholine. All subjects were defined as having moderate asthma according to at least one of the following criteria: daily symptoms, night-time symptoms $>1 \cdot$ week $^{-1}$, forced expiratory volume in one second (FEV1), peak expiratory flow (PEF) $60-80 \%$ of predicted, or PEF variability $>30 \%$ [2]. All patients had received anti-inflammatory treatment for $\leqslant 3$ months in the 2 yrs preceding the study, and none in the last 3 months. At the time of the study, all patients had active symptoms and were on rescue bronchodilators only. Three patients could not expectorate at baseline evaluation and were thus excluded from the study. The remaining 30 were enrolled and produced adequate sputum samples at all subsequent inductions (table 1). The protocol was approved by the local ethical committee. Informed written consent was given by all patients.

\section{Study design}

At a screening visit, all patients underwent spirometry, and patients with FEV $1 \geqslant 70 \%$ pred had a methacholine challenge test $(n=23)$. Every procedure was performed in the morning, at the same time of the day $\pm 1 \mathrm{~h}$. All patients recorded a daily symptom score, the use of rescue $\beta_{2}$-agonists, and morning and evening PEF on a diary card over the whole study period. There was a 2 -week run-in period (baseline) to demonstrate the degree of asthma severity. Eligible patients then entered a randomised, double-blind, parallel-group study in which they received either beclomethasone, $500 \mu \mathrm{g}$ b.i.d, or salmeterol, $50 \mu \mathrm{g}$ b.i.d. The randomisation sequence was computer-generated

Table 1. - Subject characteristics

\begin{tabular}{|c|c|c|}
\hline & BDP & Salmeterol \\
\hline Subjects $\mathrm{n}$ & 15 & 15 \\
\hline Age yrs $\#$ & $31 \pm 12$ & $37 \pm 13$ \\
\hline Atopy yes/no & $11 / 4$ & $11 / 4$ \\
\hline Smoke yes/no/ex & $1 / 10 / 4$ & $0 / 7 / 8$ \\
\hline Disease duration yrs & $13(1-31)$ & $8(2-40)$ \\
\hline \multicolumn{3}{|l|}{ No. of patients with } \\
\hline Daily symptoms & 3 & 6 \\
\hline Night-time symptoms $>1 \cdot$ week $^{-1}$ & 11 & 14 \\
\hline FEV1 or PEF $60-80 \%$ pred & 10 & 12 \\
\hline PEF variability $>30 \%$ & 1 & 0 \\
\hline
\end{tabular}

and administered by a person who was not involved in the evaluation of patients. Methacholine challenge test and sputum induction with hypertonic saline were repeated, on 2 consecutive days, after 2 and 4 weeks of treatment. Blood samples were collected before each sputum induction.

\section{Methods}

Sputum induction. Sputum was induced according to the method described by PIN et al. [7], with a slight modification [20]. Inhaled salmeterol and/or shortacting bronchodilators, but not inhaled beclomethasone, were withdrawn 24 and $8 \mathrm{~h}$, respectively, before each sputum induction. No $\beta_{2}$-agonist was administered as a pretreatment. Hypertonic saline solution was nebulised by means of an ultrasonic nebuliser (Sirius, Technomed, Florence, Italy) with a $2.8 \mathrm{~mL} \cdot \mathrm{min}^{-1}$ output, and was inhaled for 5 -min periods for $\leqslant 30 \mathrm{~min}$. $\mathrm{NaCl}$ concentration was increased at intervals of $10 \mathrm{~min}$ from $3 \%$ to $4 \%$ to $5 \%$. Every 5 min after the start of nebulisation, patients were asked to rinse their mouth and throat carefully and to try to cough sputum into a container. FEV1 was then measured. Nebulisation was stopped after 30 min or when FEV1 fell by $\geqslant 20 \%$ from baseline.

Sputum processing. Sputum samples were processed as described elsewhere [20]. After assessing sputum volume, whole sputum samples from all 30 patients were diluted with an equal volume of $0.1 \%$ dithiothreitol in phosphate-buffered saline (Sputasol; Unipath Ltd, Basingstoke, UK). Samples were incubated in a shaking bath at $37^{\circ} \mathrm{C}$ for $15 \mathrm{~min}$ and then pipetted up and down to further dissolve mucus plugs. At the end of incubation, samples were filtered through a $53 \mu \mathrm{m}$ nylon gauze to remove debris. An aliquot of sputum samples was cytocentrifuged (Cytospin; Shandon Scientific, Sewickley, PA, USA) and stained with Diff-Quik (Baxter Scientific Products, Miami, FL, USA). Two investigators, blinded to the patients' codes, each counted $\geqslant 500$ nonsquamous cells on each sputum slide. The interobserver agreement, expressed as intraclass correlation coefficient, was 0.92 for macrophages, 0.5 for lymphocytes, 0.82 for neutrophils, 0.98 for eosinophils. Therefore, the mean of the two readings on each sample were reported. Macrophage, lymphocyte, neutrophil and eosinophil counts were expressed as percentages of 500 inflammatory cells, excluding squamous cells. The remainder of the sputum sample was centrifuged at $450 \times g$ for $10 \mathrm{~min}$. The supernatant was collected and stored at $-80^{\circ} \mathrm{C}$ for further analysis. The cell pellets were resuspended in normal saline for total cell counts with the Türk staining and cell viability assessment by Trypan blue exclusion in a haemocytometer. Samples with cell viability $<70 \%$ were discarded. In cases of low cell viability at baseline, the patient was excluded from the study. At subsequent evaluations, sputum induction was rescheduled after $24 \mathrm{~h}$.

Blood processing. Blood samples were examined for total and differential cell counts. The remainder were 
centrifuged at $1,000 \times g$ for $10 \mathrm{~min}$ after $60 \pm 10 \mathrm{~min}$ of rest at room temperature to allow clotting. The supernatant was then centrifuged again to ensure complete cell removal. Serum was then collected and stored at $-80^{\circ} \mathrm{C}$ for further analysis.

Eosinophil cationic protein and eosinophil protein $X$ measurements. Eosinophil cationic protein (ECP) and eosinophil protein $\mathrm{X}$ (EPX) in sputum supernatant and serum were measured by means of a radioimmunoassay (Pharmacia RIA, Uppsala, Sweden) (normal values in serum: ECP $2.3-16 \mu \mathrm{g} \cdot \mathrm{L}^{-1}$, EPX 8.2-38.2 $\mu \mathrm{g} \cdot \mathrm{L}^{-1}$; lower detection limit: $\left.<2 \mu \mathrm{g} \cdot \mathrm{L}^{-1}\right)$. Since ECP and EPX were higher than the upper detection limit of the method in four and seven sputum samples respectively, these samples were diluted $1: 10$ and the measurements were repeated. Sputum ECP and EPX measurements were corrected (multiplied by 2) for the processing dilution with dithiothreitol.

Methacholine challenge test. Inhaled salmeterol and/or short-acting bronchodilators, but not inhaled beclomethasone, were withdrawn 24 and $8 \mathrm{~h}$, respectively, before each test. Methacholine (Sigma, St. Louis, MO, USA) was delivered by a DeVilbiss 646 jet nebuliser using a procedure described previously [21]. The cumulative provocative dose producing a $20 \%$ fall in the FEV1 (PD20) was computed. A value of $<1,000 \mu \mathrm{g}$ of methacholine was considered positive for bronchial hyperresponsiveness.

Peak expiratory flow, symptom evaluation, rescue $\beta_{2}$-agonist use. Symptoms (wheezing, chest tightness, shortness of breath, cough) were rated on a scale from 0 (none) to 4 (never slept because of asthma) for nighttime symptoms and 0 (none) to 5 (could not perform common daily activities because of asthma) for daytime symptoms, and were added up to give the average daily symptom score [22]. Predrug morning $\mathrm{PEF}$ was expressed as \% predicted. PEF variability, expressed as amplitude \% mean, was calculated as follows:

$$
\frac{\text { (highest } \mathrm{PEF} \text { value }- \text { lowest } \mathrm{PEF} \text { value) }}{\text { mean daily value } \times 100}
$$

and a value of $\geqslant 10 \%$ was considered high. Rescue $\beta_{2}$-agonist use was evaluated by recording the number of times that patients needed to inhale $\geqslant 1$ puffs of short-acting $\beta_{2}$-agonists.

\section{Analysis}

Cell counts and sputum volume are expressed as median (range). The symptom score, morning PEF, daily PEF amplitude per cent mean, per cent of days with abnormal PEF amplitude per cent mean, and short-acting rescue $\beta_{2}$-agonist use were averaged over the last 7 days before each visit and expressed as median (range) except for morning PEF and daily PEF amplitude per cent mean, which are expressed as mean \pm SD. FEV1 is also expressed as mean \pm SD. The provocative dose of methacholine causing a 20\% fall in FEV1 (PD20) is expressed as geometric mean, and was log transformed for comparisons. The Mann-Whitney U-test and Friedman test were used to compare differential sputum cell counts, ECP and EPX, blood eosinophil percentages, serum ECP and EPX between and within treatments respectively. An unpaired t-test and analysis of variance (ANOVA) for repeated measures were used to compare FEV1 and $\log$ PD20 methacholine between and within treatments respectively.

\section{Results}

\section{Inflammatory markers}

Baseline sputum and blood eosinophil percentages, sputum/serum ECP and EPX levels were no different between beclomethasone and salmeterol groups (figs. 1-3, table 2). After 2 and 4 weeks of beclomethasone treatment, sputum and blood eosinophils, as well as sputum and serum ECP and EPX, significantly decreased. With salmeterol treatment, only serum EPX decreased, after 4 weeks. Sputum volume, total cell counts, and differential cell counts for macrophages, lymphocytes and neutrophils did not change after either treatment. Cell viability was $>70 \%$ in all collected samples, so that no sputum induction had to be rescheduled.

a)

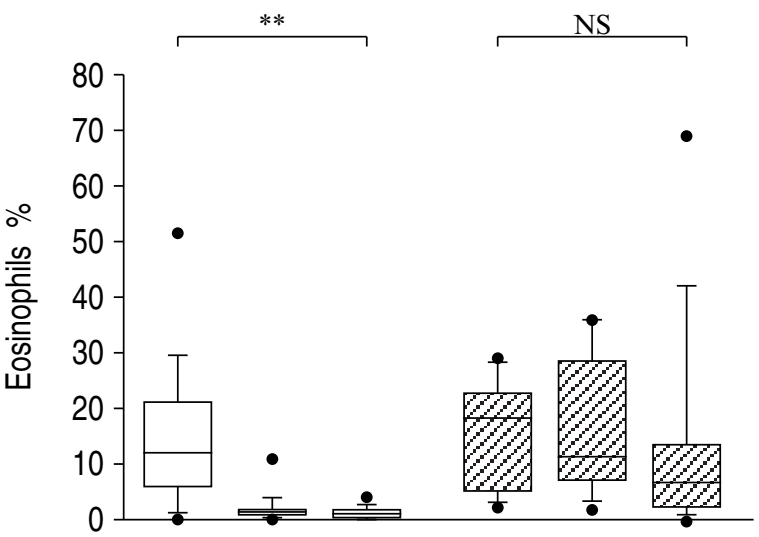

b)

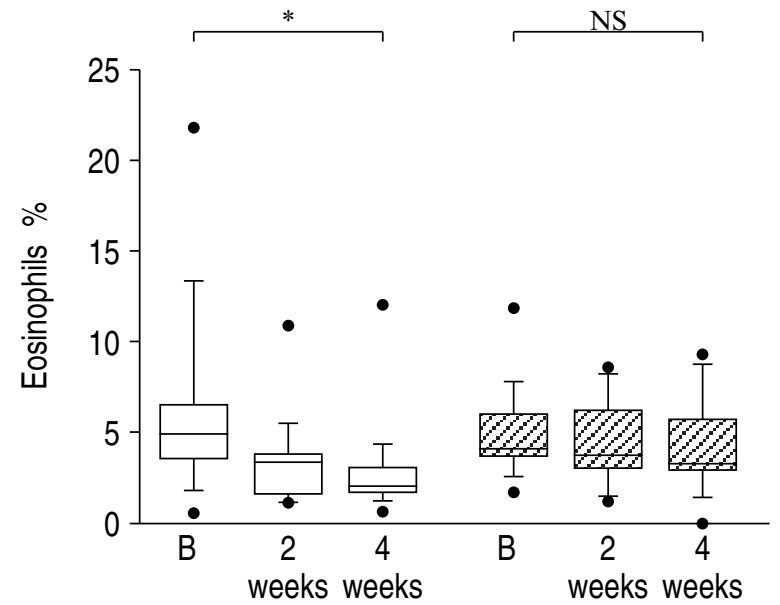

Fig. 1.-a) Sputum and b) blood eosinophils before (B) and 2 and 4 weeks after treatment. $\square$ : beclomethasone dipropionate, $500 \mu \mathrm{g}$ b.i.d; $\mathbb{Z}$ : salmeterol, $50 \mu \mathrm{g}$ b.i.d. ${ }^{*}$ : $\mathrm{p}<0.05$; **: $\mathrm{p}<0.01$. 
a)

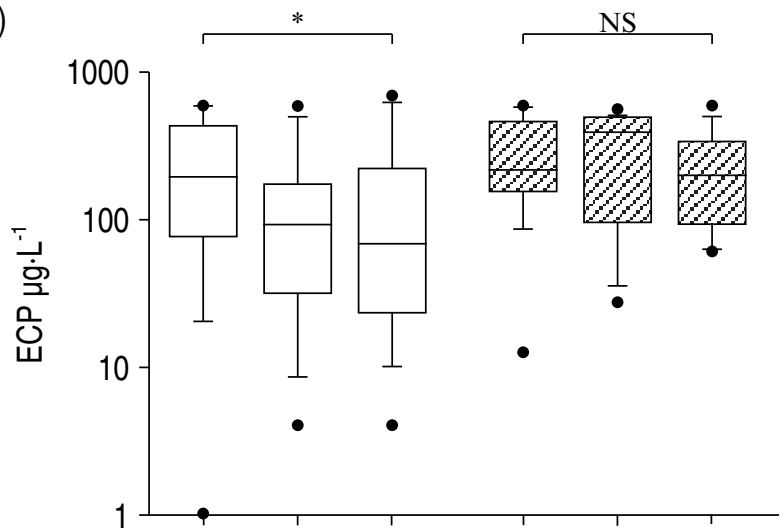

b)

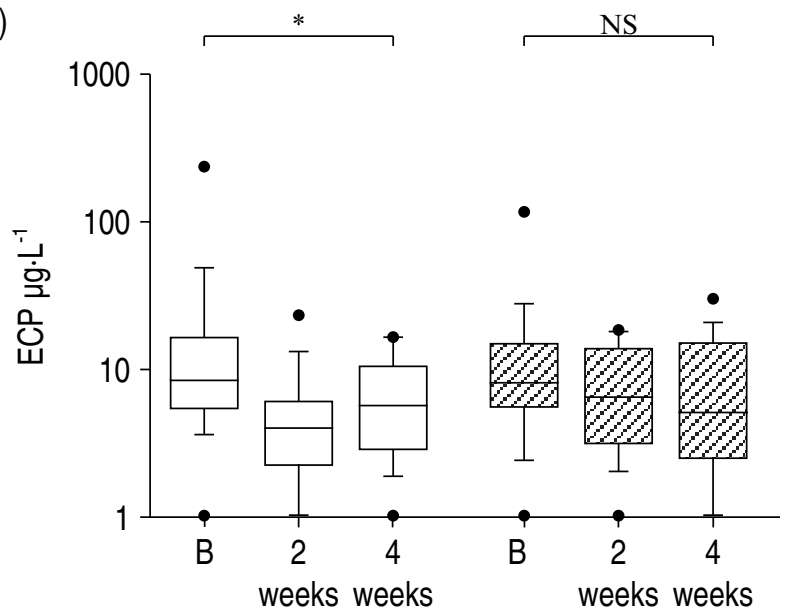

Fig. 2. - a) Sputum and b) blood eosinophil cationic protein (ECP) before (B) and 2 and 4 weeks after treatment. $\square$ : beclomethasone dipropionate, $500 \mu \mathrm{g}$ b.i.d; $\mathbb{Z}$ : salmeterol, $50 \mu \mathrm{g}$ b.i.d. *: $\mathrm{p}<0.05$.

\section{Clinical and functional data}

Baseline FEV1, morning PEF, and PD20 methacholine were no different between the beclomethasone and salmeterol groups. After 2 and 4 weeks of treatment, FEV1 and morning PEF significantly improved in the beclomethasone group but not in the salmeterol group (table 3). PD20 methacholine tended to increase with treatment and was higher in the beclomethasone group, without reaching statistical significance $(\mathrm{p}=0.11)$.

Baseline daily PEF amplitude $\%$ mean, percentage of days with abnormal PEF amplitude $\%$ mean, daily symptom score and use of rescue $\beta_{2}$-agonist were no different between beclomethasone and salmeterol groups. After treatment, they all significantly improved in both groups, although after 4 weeks the improvement in symptom score tended to be higher in beclomethasone-treated patients ( $\mathrm{p}=0.05$, table 3 ).

\section{Discussion}

In the present study it was shown that inhaled beclomethasone, at the daily dose recommended by the international guidelines for asthma treatment [2], but not salmeterol, decreased eosinophilic inflammation a)

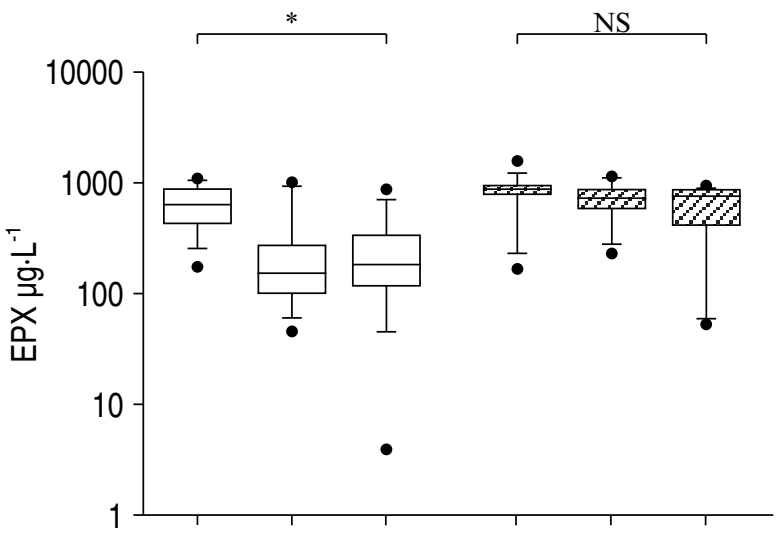

b)

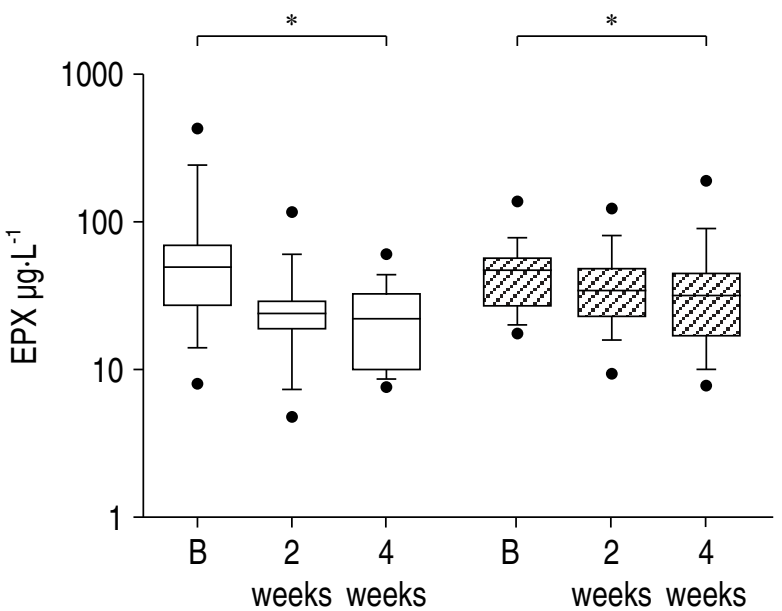

Fig. 3.-a) Sputum and b) blood eosinophil protein X (EPX) before (B) and 2 and 4 weeks after treatment. $\square$ : beclomethasone dipropionate, $500 \mu \mathrm{g}$ b.i.d; $\mathbb{Z}$ : salmeterol, $50 \mu \mathrm{g}$ b.i.d. *: $\mathrm{p}<0.05$.

in sputum and blood in steroid-naïve asthmatic patients. Beclomethasone improved the symptom score, the use of rescue $\beta_{2}$-agonist, PEF variability, FEV1, and morning PEF values, whereas salmeterol only improved the symptom score, the use of rescue $\beta_{2}$-agonist, and PEF variability. Neither treatment improved methacholine responsiveness. After beclomethasone, functional data improved within 2 weeks of treatment, and paralleled the improvement in both sputum and blood eosinophilic markers.

Previous studies have reported the effect of inhaled steroids on airway inflammation in asthma. FAHY and BOUSHEY [11] showed that low steroid doses $(168 \mu \mathrm{g}$ b.i.d) improved clinical and functional data, but had only mild effects on airway inflammation. JATAKANON et al. [13] studied a group of mild asthmatic patients treated with very high steroid doses $(800 \mu \mathrm{g}$ b.i.d), and found a significant improvement in both airway function and sputum eosinophils, but not in sputum ECP or tumour necrosis factor (TNF)- $\alpha$. The lack of effect on soluble mediators was not reported, and therefore cannot be compared with the present data. In another study, the same authors compared the same group of patients with asthmatic patients of a similar degree treated with lower doses of inhaled steroid, and also found that $400 \mu \mathrm{g}$ budesonide, but not $100 \mu \mathrm{g}$, significantly improved airway inflammation and lung 
Table 2. - Induced sputum and blood indices measured before and after treatment

\begin{tabular}{|c|c|c|c|c|c|c|}
\hline & \multicolumn{3}{|c|}{ Beclomethasone } & \multicolumn{3}{|c|}{ Salmeterol } \\
\hline & Baseline & After 2 weeks & After 4 weeks & Baseline & After 2 weeks & After 4 weeks \\
\hline \multicolumn{7}{|l|}{ Sputum } \\
\hline Eosinophils \% & $12.0(0.2-51.4)$ & $1.8(0-10.8)^{(* *)}$ & $1.0(0-4)^{(* *)}$ & $18.1(2.7-29)$ & $11.3(2-35.5)^{* *}$ & $7.0(0-69.1)^{* *}$ \\
\hline $\mathrm{ECP} \mu \mathrm{g} \cdot \mathrm{L}^{-1}$ & $200(1-616)$ & $94(4-600)^{(*)}$ & $68(4-700)^{(*)}$ & $220(13-620)$ & $400(28-560)^{* *}$ & $200(62-600)^{*}$ \\
\hline $\mathrm{EPX} \mu \mathrm{g} \cdot \mathrm{L}^{-1}$ & $640(180-1200)$ & $157(48-1040)^{(*)}$ & $185(1-44.6)^{(*)}$ & $900(180-1600)$ & $860(240-1200)^{* *}$ & $800(56-1000)^{*}$ \\
\hline \multicolumn{7}{|c|}{ ( } \\
\hline Eosinophils $\%$ & $4.8(0.7-22)$ & $3.2(1.2-10.9)^{(*)}$ & $2.2(0.6-12)^{(*)}$ & $4.1(1.8-11.8)$ & $3.8(1.2-8.5)$ & $3.3(0.2-9.4)^{*}$ \\
\hline $\mathrm{ECP} \mu \mathrm{g} \cdot \mathrm{L}^{-1}$ & $8.0(1-250)$ & $4.0(1-23)^{(*)}$ & $5.5(1-17)^{(*)}$ & $8.0(1-120)$ & $6.5(1-19)$ & $5.0(1-31)$ \\
\hline EPX $\mu \mathrm{g} \cdot \mathrm{L}^{-1}$ & $48.5(8-450)$ & $23.5(4.8-120)^{(*)}$ & $22.0(7.9-61)^{(*)}$ & $48.0(18-140)$ & $35.0(10-130)$ & $32.0(8-200)^{*}$ \\
\hline
\end{tabular}

Values are presented as median (range). ECP: eosinophil cationic protein; EPX: eosinophil protein $\mathrm{x}$. *: $\mathrm{p}<0.05$ between treatments; ${ }^{* *}: \mathrm{p}<0.01$ between treatments; ${ }^{(*)}: \mathrm{p}<0.05$ from baseline; ${ }^{\left({ }^{*}\right)}: \mathrm{p}<0.01$ from baseline.

function [12]. In a study including a large number of patients, MeIJer et al. [14] compared the effects of two different doses of inhaled fluticasone $(1,000$ or $250 \mu \mathrm{g}$ b.i.d) and oral prednisolone $\left(30 \mathrm{mg} \cdot \mathrm{day}^{-1}\right)$ on lung function and airway inflammation. They showed that inhaled steroids were at least as effective as oral steroids, and that the lowest dose of fluticasone had far less systemic effects than the other two treatments. Thus, it is now well established that adequate doses of inhaled steroids effectively improve eosinophilic airway inflammation.

Long-acting $\beta_{2}$-agonists have been shown to have some anti-inflammatory effects in experimental models, including effects on sputum eosinophils [17] and blood ECP [23]. However, treatment with longacting $\beta_{2}$-agonists as monotherapy for longer time periods has demonstrated marginal or no effects on airway inflammation [19, 24, 25]. In this study, no relevant anti-inflammatory effect of salmeterol, despite the improvement in symptoms and PEF variability, was shown. Indeed, only serum EPX significantly decreased after 4 weeks of salmeterol treatment. A similar observation has been reported previously [23] for serum ECP using a short-term course of inhaled salmeterol. The authors ascribed the decrease in serum ECP to the inhibition of eosinophil degranulation. The improvement in PEF variability is not surprising, because salmeterol reduces bronchoconstriction. The lack of improvement in FEV1 might, at least partially, be because salmeterol was withdrawn $24 \mathrm{~h}$ before the measurement. The lack of improvement in morning PEF may partly be due to it being measured before inhaling salmeterol, and thus the measurement was only partially affected by the latest inhalation, taken $8-10 \mathrm{~h}$ before PEF measurement. However, this suggests that salmeterol alone is not enough to obtain a persistent improvement in airway calibre.

Turner et al. [19] compared the effects of salmeterol and beclomethasone on mild asthma exacerbations, and found that salmeterol improved clinical parameters but not markers of eosinophilic inflammation. McIvor et al. [26] evaluated the effect of adding salmeterol to a progressive reduction in the inhaled steroid dose in patients with asthma. They observed that salmeterol controlled symptoms and airway function but not airway inflammation. Thus, salmeterol is not recommended as single therapy in asthma.

The study was designed to compare the effects of beclomethasone with those of salmeterol in controlling symptoms, respiratory function, and airway inflammation. It has been reported that airway inflammation may be present [11] and increase [26] despite good functional data and absence of symptoms, and this may lead to asthma exacerbation. It is therefore useful to know whether treatment is acting on every

Table 3. - Functional and clinical indices measured before and after treatment

\begin{tabular}{|c|c|c|c|c|c|c|}
\hline & \multicolumn{3}{|c|}{ Beclomethasone } & \multicolumn{3}{|c|}{ Salmeterol } \\
\hline & Baseline & $\begin{array}{c}\text { After } \\
2 \text { weeks }\end{array}$ & $\begin{array}{c}\text { After } \\
4 \text { weeks }\end{array}$ & Baseline & $\begin{array}{c}\text { After } \\
2 \text { weeks }\end{array}$ & $\begin{array}{c}\text { After } \\
4 \text { weeks }\end{array}$ \\
\hline FEV1 \% pred & $87.5 \pm 13.8$ & $96.5 \pm 15.1^{*}$ & $94.7 \pm 12.1^{*}$ & $80.9 \pm 18.2$ & $83.3 \pm 17.3^{(*)}$ & $84.3 \pm 16.2^{(*)}$ \\
\hline PD20 $\mu \mathrm{g}^{\#{ }^{*}}$ & $92(2.5)$ & $117(3.5)$ & $137(4.2)$ & $109(2.9)$ & $73(2.9)$ & $74(3.7)$ \\
\hline PEF $\%$ pred & $81.7 \pm 14.0$ & $88.7 \pm 14.5^{* *}$ & $91.1 \pm 13.5^{* *}$ & $73.6 \pm 15.2$ & $75.0 \pm 12.4^{(*)}$ & $78.2 \pm 12.8^{(*)}$ \\
\hline PEF AM \% & $16 \pm 14$ & $9 \pm 7 *$ & $7 \pm 4 *$ & $13 \pm 5$ & $11 \pm 7 *$ & $8 \pm 4 *$ \\
\hline $\mathrm{Abn} \mathrm{AM} \%$ of days & $36(0-100)$ & $16(0-64) * *$ & $18(0-64)^{* *}$ & $43(0-83)$ & $36(0-77)^{* *}$ & $20(0-67)^{* *}$ \\
\hline Symptom score & $1.2(0.2-2.8)$ & $0.2(0-1.2)^{* *}$ & $0(0-1.2)^{* *}$ & $1.6(0.7-4.6)$ & $0.4(0-1.5)^{* *}$ & $0.2(0-2.1)^{* * \text {, }}$ \\
\hline$\beta_{2}$-agonist use & $1.0(0-3.5)$ & $0(0-2.0)^{* *}$ & $0(0-1.6)^{* *}$ & $1.0(0.2-4.6)$ & $0.1(0-0.8)^{*}$ & $0.1(0-0.7)^{* *}$ \\
\hline
\end{tabular}

Values are expressed as mean \pm SD or median (range). FEV1: forced expiratory volume in one second; PD20: provocative dose causing a 20\% fall in the FEV1; PEF: peak expiratory flow; $\%$ pred: \% predicted; AM: amplitude \% mean; Abn AM: abnormal amplitude \% mean. \#: geometric mean (geometric SD); *: p $<0.05$ from baseline; **: p $<0.01$ from baseline; $\left.{ }^{*}\right)$ : $p<0.05$ between treatments; ${ }^{\uparrow}: \mathrm{p}=0.05$ between treatments. 
single aspect of the disease. While beclomethasone controls symptoms, respiratory function, and airway inflammation, salmeterol only improves clinical and functional data, and not eosinophilic inflammation. Whether adding salmeterol to low-dose inhaled corticosteroids adequately controls not only clinical but biological markers of asthma better than increasing the dose of inhaled corticosteroids is not clearly defined [27, 28].

Inhaled steroid treatment improved FEV1 but not methacholine responsiveness. This result is in agreement with the hypothesis that bronchial hyperresponsiveness depends on a wide range of factors [29], and that acute inflammation may not be the most relevant factor in the response to methacholine, which may, instead, require longer treatment duration to improve.

To conclude, it was shown that treating asthmatic patients with appropriate inhaled steroid doses, according to international guidelines, not only controls symptoms but also improves airway inflammation. By contrast, salmeterol monotherapy was effective on symptoms and peak expiratory flow variability, but only marginally affected markers of airway eosinophilic inflammation. Thus, it was confirmed that the use of salmeterol alone is not recommended for the long-term treatment of asthma.

Acknowledgements. The authors would like to thank. M. De Santis and E. Masino for technical assistance.

\section{References}

1. Djukanovic R, Roche WR, Wilson JW, et al. Mucosal inflammation in asthma. Am Rev Respir Dis 1990; 142: 434- 457.

2. Global Initiative on Asthma. National Institutes of Health. Global strategy for asthma management and prevention. NHLBI workshop report 1995. Publication No. 95-3659, 1995

3. Woolcock AJ, Jenkins CR. Clinical responses to corticosteroids. In: Kaliner MA, Barnes PJ, Persson CGA, eds. Asthma. Its Pathology and Treatment. New York, Dekker, 1991; pp. 633-665.

4. Juniper EF, Kline PA, Vanzieleghem MA, Ramsdale EH, O'Byrne PM, Hargreave FE. Effect of long-term treatment with an inhaled corticosteroid (budesonide) on airway hyperresponsiveness and clinical asthma in nonsteroid-dependent asthmatics. Am Rev Respir Dis 1990; 142: 832-836.

5. Duddridge M, Ward C, Hendrick DJ, Walters EH. Changes in bronchoalveolar lavage inflammatory cells in asthmatic patients treated with high dose inhaled beclomethasone dipropionate. Eur Respir J 1993; 6: 489-497.

6. Jeffery PK, Godfrey RW, Adelroth E, Nelson F, Rogers A, Johansson SA. Effects of treatment on airway inflammation and thickening of basement membrane reticular collagen in asthma. Am Rev Respir Dis 1992; 145: 890-899.

7. Pin I, Gibson PG, Kolendowicz R, et al. Use of induced sputum cell counts to investigate airway inflammation in asthma. Thorax 1992; 47: 25-29.
8. Venge P. Serum measurements of eosinophil cationic protein (ECP) in bronchial asthma. Clin Exp Allergy 1993; 23: Suppl. 2, 3-7.

9. Pizzichini MMM, Pizzichini E, Clelland L, et al. Sputum in severe exacerbations of asthma. $\mathrm{Am}$ J Respir Crit Care Med 1997; 155: 1501-1508.

10. Claman DM, Boushey HA, Liu J, Wong H, Fahy JV. Analysis of induced sputum to examine the effects of prednisone on airway inflammation in asthmatic subjects. J Allergy Clin Immunol 1994; 94: 861-869.

11. Fahy JV, Boushey HA. Effect of low-dose beclomethasone dipropionate on asthma control and airway inflammation. Eur Respir J 1998; 11: 1240-1247.

12. Jatakanon A, Kharitonov S, Lim S, Barnes PJ. Effect of differing doses of inhaled budesonide on markers of airway inflammation in patients with mild asthma. Thorax 1999; 54: 108-114.

13. Jatakanon A, Lim S, Chung KF, Barnes PJ. An inhaled steroid improves markers of airway inflammation in patients with mild asthma. Eur Respir $J$ 1998; 12: 1084-1088.

14. Meijer RJ, Kerstjens HAM, Arends LR, Kauffman HF, Koëter GH, Postma DS. Effects of inhaled fluticasone and oral prednisolone on clinical and inflammatory parameters in patients with asthma. Thorax 1999; 54: 894-899.

15. Tilles SA, Nelson HS. Long-acting inhaled beta agonists. J Asthma 1995; 32: 397-404.

16. Butchers PR, Vardey CJ, Johnson M. Salmeterol: a potent and long-acting inhibitor of inflammatory mediator release from human lung. Br $J$ Pharmacol 1991; 104: 672-676.

17. Dente FL, Bancalari L, Bacci E, et al. Effect of a single dose of salmeterol on the increase in airway eosinophils induced by allergen challenge in asthmatic subjects. Thorax 1999; 54: 622-624.

18. Pizzichini MMM, Kidney JC, Wong BJ, et al. Effect of salmeterol compared with beclomethasone on allergen-induced asthmatic and inflammatory responses. Eur Respir J 1996; 9: 449-455.

19. Turner MO, Johnston PR, Pizzichini E, Pizzichini MMM, Hussack PA, Hargreave FE. Antiinflammatory effects of salmeterol compared with beclomethasone in eosiniphilic mild exacerbations of asthma: a randomized, placebo-controlled trial. Can Respir $J$ 1998; 5: 261-268.

20. Bacci E, Cianchetti S, Paggiaro PL, et al. Comparison between hypertonic and isotonic saline-induced sputum in the evaluation of airway inflammation in subjects with moderate asthma. Clin Exp Allergy 1996; 26: $1395-1400$.

21. Paggiaro PL, Bacci E, Paoletti $\mathrm{P}$, et al. Bronchoalveolar lavage and morphology of the airways after cessation of exposure in asthmatic subjects sensitized to toluene diisocyanate. Chest 1990; 98: 536-542.

22. Paggiaro PL, Giannini D, Di Franco A, Testi R. Comparison of inhaled salmeterol and individually dose-titrated slow-release theophylline in patients with reversible airway obstruction. Eur Respir J 1996; 9: 1689-1695.

23. Di Lorenzo G, Morici G, Norrito F, et al. Comparison of the effects of salmeterol and salbutamol on clinical activity and eosinophil cationic protein serum levels during the pollen season in atopic asthmatics. Clin Exp Allergy 1995; 25: 951-956.

24. Gardiner PV, Ward C, Booth H, Allison A, Hendrick DJ, Walters EH. Effect of eight weeks of treatment 
with salmeterol on bronchoalveolar lavage inflammatory indices in asthmatics. Am J Respir Crit Care Med 1994; 150: 1006-1011.

25. Wallin A, Sandström T, Söderberg M, et al. The effects of regular inhaled formoterol, budesonide on mucosal inflammation and clinical indices in mild asthma. Am J Respir Crit Care Med 1999; 158: 79-86.

26. McIvor RA, Pizzichini E, Turner MO, Hussack P, Hargreave FE, Sears MR. Potential masking effect of salmeterol on airway inflammation in asthma. Am J Respir Crit Care Med 1998; 158: 924-930.

27. Pauwels RA, Lofdahl CG, Postma DS, et al. Effect of inhaled formoterol and budesonide on exacerbations of asthma. Formoterol and Corticosteroids Establishing Therapy (FACET) International Study Group. $N$ Engl J Med 1997; 337: 1405-1411.

28. Kips JC, O'Connor BJ, Inman MD, Svensson K, Pauwels RA, O'Byrne PM. A long-term study of the antiinflammatory effect of low-dose budesonide plus formoterol versus high-dose budesonide in asthma. Am J Respir Crit Care Med 2000; 161: 9961001.

29. Holgate ST, Beasley R, Twentyman OP. The pathogenesis and significance of bronchial hyperresponsiveness in airways disease. Clinical Science 1987; 73: 561-572. 